\title{
Formation And Development Of The National Geo-Economic Perspective Of Uzbekistan
}

\author{
Kobilov Rustam Rajabboyevich \\ Head Of The Samarkand Branch Of The Agency For Public Service Development Under The \\ President Of The Republic Of Uzbekistan
}

Journal Website:

http://usajournalshub.c

om/index,php/tajssei

Copyright: Original

content from this work

may be used under the

terms of the creative

commons attributes

4.0 licence.

\section{ABSTRACT}

In this article, the issues of forming the National geo-economic image of Uzbekistan were widely discussed. The comprehensive development of the economic excellence of the current New Uzbekistan, strengthening its economic supply on the basis of world standards is fully covered in the instructions. In the minds of the people, there is an opinion about economic thinking, about the main imprints of the formation of economic culture in their values.

\section{KEYWORDS}

Uzbekistan, people, consciousness, Culture, Economy, geo-economic context, development, geographical location.

\section{INTRODUCTION}

The independent state of Uzbekistan will first of all have to form and develop its national geo-economic space in order to implement geo-economic policy within the framework of the geo-economic landscape of today's world, that is, to solve its tasks of strategic importance with the aim of earning and making profit. In general, the geo-economic space of today's world is not created by itself, but is formed, formed and developed as a 
result of the efforts of the national economy to find a specific place from the World Economic spaces.

The work on the formation and development of the National geo-economic space of the state of Uzbekistan is carried out step by step on the basis of fulfillment of the abovementioned conditions, thorough study of one or more of these aspects, scientific processing.

The work on the formation and development of the National geo-economic space of our country can be carried out by dividing it into the following stages in sequence.

At the first stage, in order to create a National geo-economic space of our country, it is necessary to work out the development and continuous improvement of its ideology, theoretical core, structural structure, joints of various forms, their interpretations on the basis of a national idea that expresses the interests of the Uzbek people who represent it.

At the second stage, it is necessary to sufficiently collect information necessary for the materialization of one or more parts of the National geo-economic space of our country, to clarify the system of recording quantitative and qualitative indicators of the changes that have occurred and will occur, to analyze the information technologies that can be applied to the work carried out, etc.

At the third stage, the national geo-economic space of our country includes topological (continuity, dimensionality, order, compactness, continuity of time, one dimensional, irreversibility, linear connection to the topological features of space and it reflects the fundamental qualitative aspects of existencet) [1.12] and it is necessary to carry out the work on simple dimensions to bring them closer together, that is, to create logical and mathematical models.

At the fourth stage, it is necessary to carry out the implementation of high-level geoeconomic technologies for productive use of the National geo-economic space of our country. Because in bunda, important tasks of strategic importance, key decisions, a high geo-economic Technology category are developed, different variants of different situations are seen playing. A system of rapid delivery of information to the appropriate level of "consumers"is formed.

At the fifth stage, it is necessary to create a methodological and methodological base aimed at training specialists to work within the framework of the National geo-economic landscape of our country.

In order to carry out geo-economic policy within the framework of today's world geoeconomic space, training of personnel with the ability to think geo-economic is required. To do this, it will be necessary to carry out the development of specialists engaged in strategic and tactical issues of geo-economic policy implementation in higher and secondary special educational institutions.

Proceeding from the above points of view, the concept of "national geo-economic landscape of Uzbekistan" can be described as follows: philosophical.

The National geo-economic space of Uzbekistan is a part of the geo-economic space of the world, which has a local character, which characterizes the types of income generated as a result of the integration of the Uzbek people with other 
peoples for the purpose of earning and earning profits depending on their geographical location, economic potential, values, historical memory, communication opportunities, impact zones, geo-economic Analyzing the current state of formation and development of the National geo-economic space of Uzbekistan from the social philosophical point of view, we can see the following.

The following is the national-state and administrative-territorial structure, the role of state authorities and governing bodies in the formation and development of the National geo-economic space of our country.

The independent state of Uzbekistan is located in the central part of Central Asia, it borders on the Kyrgyz Republic (at a distance of 1099 kilometers) in the East and North-East, the Republic of Kazakhstan in the North and North-West (at a distance of 2203 kilometers), the Republic of Tajikistan in the South and South-East (at a distance of 1161 kilometers), The total length of the border is 6221 kilometers. Between its northern and southern edge points-925 kilometers, from West to East - 1400 kilometers, the total area is $448,9 \quad(447,7)$ thousand square kilometers[2.4] . Therefore, the geographical location of the territory of our country as a ring connecting East and West, South and North with each other is considered one of the most convenient places for geo-economic policy of our close and distant troops.

The population of Uzbekistan is 34.8 million. the person is (2020y).All of them" have the same rights and freedoms and are equal before the law, regardless of gender, race, nationality, language, religion, social origin, nationality, personal and social status (Article 18) " [3.8]. Hence, the number of inhabitants and their equality before the law is a guarantee of the formation and development of the National geo-economic landscape.

The issue of formation of the organizational and economic part of the National geo economic space of Uzbekistan is defined in the Constitution of the Republic of Uzbekistan: "development of market relations" forms the basis of the economy of Uzbekistan in various forms of property... Private property, like other forms of property, is inviolable and protected by the state. The owner can be deprived of his property only in cases provided for by law and in order (Article 53). The owner owns the property at his own discretion, uses it and dispose of it. The use of property must not cause harm to the ecological environment, violate the rights of citizens, legal entities and the interests of the state, as well as protected by law (Article $54) "[3.11]$,-is based on the law.

Over the past 30 years, the system of individual ownership, which remained from the former USSR, has been liquidated, and instead of it, an unprecedented work has been carried out on the formation, formation and development of a market economy based on multi-ownership. More precisely, a new class of property owners, who became owners of private property, appeared. A new generation of small businesses and private entrepreneurs began to operate economically on the basis of innovative methods. Therefore, our President Sh.M.Mirziyoyev: "when an active entrepreneur says, We understand business people who are able to produce competitive products, most importantly, create new jobs, feed not only himself and his family, but also bring profit to the whole society... If necessary, we should give them a comprehensive opportunity to gain experience in leading companies and 
organizations abroad and to cooperate in a mutually beneficial manner"[4.87],- he said.

Currently, $74 \%$ of the employed population works in this area, their share in the gross domestic product is $52,5 \%$. And its share in product exports increased by three marotabs in the last 15 years, and today this seer has reached 27 percent. In the last five years, the number of enterprises engaged in export activities increased by 1.5 times, the number of small businesses increased by 1.6 times[5.124] . So, in the formation of the National geoeconomic space of our country, it is necessary to look at small business and private entrepreneurship as one of the active subjects of the power, geo-economic policy that drives society.

\section{CONCLUSIONS}

1. The acceleration of the processes of the introduction of scientific and technical achievements into the direct production by the 21st century also sends a sharp change in the worldview of people. And this is due to the fact that, having conducted a scientific analysis of the individual, private aspects of various changing worldviews that are taking place in the minds of people, finding common similar sides, bringing them to some kind of philosophical consensus, on this basis, establishing peace and stability in the world.

2. One of the factors that bring people to philosophical consensus in the field of economics is the expression from the formation of scientific imaginations about the geo-economic space of today in the minds of every individual, elat, nation and people. To do this, it is necessary to create, formulate and develop the geoeconomic space of today's world.
3. The concept of "geo-economic space of today's world" as a philosophical category, which is part of the Privatelooking form of the concept of "scientific space of the world", is a synthesis of knowledge that includes interrelation, communication, influence and reflection between different sides of socio-economic processes taking place in geo-economic spaces of the world of economy, qualitative and quantitative changes.

\section{REFERENCES}

1. Turaev B.O. Universal features of space and time / / Journal of philosophy and Law, Special Issue, 2011. - P.12

2. World countries: brief reference / / responsible editor A.Hezretkulov, - T.: "East", 2006. - P. 384.

3. The Constitution of The Republic Of Uzbekistan.- T.:Uzbekistan, 2017- P.40.

4. Address of the president of the Republic of Uzbekistan Shavkat Mirziyoyev to the Oliy Majlis// himself. The consent of our people is the highest assessment given to our activities. 3-volume. - Tashkent: "Uzbekistan", 2018. - P.508.

5. A scientific and popular guide devoted to the study of the appeal of the president of the Republic of Uzbekistan Shavkat Mirziyoyev in the Oliy Majlis and the promotion of it among the general public. T.: "Spirituality", 2018. - P.320. 